\title{
Is consanguinity prevalence decreasing in Saudis?: a study in two generations
}

\author{
Arjumand Sultan Warsy ${ }^{1}$ May Hamad Al-Jaser ${ }^{2}$, Abeer Albdass ${ }^{1}$, Sooad Al-Daihan ${ }^{1}$, Mohammad Alanazi ${ }^{1}$
}

1. Department of Biochemistry, College of Science, King Saud University, Riyadh, Saudi Arabia.

2. Department of Zoology, College of Science, King Saud University, Riyadh, Saudi Arabia.

\begin{abstract}
Background: Saudi population is unique in that there is a strong preference for cousin marriages in the general population. We studied the prevalence of consanguinity in educated Saudi females and compared the results with the results obtained in their parents, to access if a generation difference in which extensive educational activities have prevailed to inform the people of the influence of cousin marriages on health, has made any difference in prevalence of consanguineous marriages.

Method: A total of 600 Saudi women (421 university students and 179 women attending outpatients' clinics) were interviewed about their own and their parents' consanguinity.

Results: The total consanguinity (first and second cousins) was $29.7 \%$ in the parents. Consanguinity was significantly higher among the daughters than the parents, where $37.9 \%$ of the 293 married women had consanguineous marriages. The prevalence of consanguinity was studied in different age groups, though no significant pattern was observed. A strong correlation was found between consanguinity of parents and their daughters; consanguinity was highest $(52.3 \%)$ in the daughters of parents who were themselves consanguineous.

Conclusion: The results did not reveal any decrease in the prevalence of consanguinity over a generation. This shows that the tradition of marrying within the family is a preferred practice, despite the awareness that certain genetic disorders occur at a higher frequency in cousin marriages. There is a need at the primary health care level to inform the public of the consequences of this common practice.
\end{abstract}

Key words: Consanguinity; Saudis; First cousin marriage; second cousin marriage; Middle East.

African Health Sciences 2014; 14(2):314-321

DOI: http://dx.doi.org/10.4314/ahs.v14i2.5

\section{Introduction}

Consanguinity (Kon'san'-guin'it E), is a word derived from two Latin words: con meaning 'shared' and sanguis meaning' blood', and is used to describes relationship between two people who are related as they share common ancestors (a shared blood relationship) [cognatio naturalis]. Consanguineous marriages refer to marriages between two people, genetically related, by descent, from a common ancestor ( $\mathrm{F} \geq 0.0156)$ [1].

Consanguineous mating and inbreeding have been a subject of human biological inquiry since George Darwin, himself the son of a marriage between Charles Darwin and his cousin Emma Wedgewood [2], who

\section{Corresponding author: \\ Arjumand S. Warsy \\ Department of Biochemistry \\ College of Science \\ P. O. Box No. 22452 \\ King Saud University \\ Riyadh 11495, Saudi Arabia \\ Phone: 00966-501832032 \\ Email: aswarsy@ksu.edu.sa}

investigated the relative academic and athletic performance of people from consanguineous and non-consanguineous marriages [3-4]. The rate at which consanguinity exists varies from one population to another [5,6]. Among the European populations the consanguinity rates are generally less than $0.5 \%$, while in North Africa, Saudi Arabia and Southern and Western Asian populations $22-55 \%$ of all unions are consanguineous $[7,8]$. In the majority of the states of the United States of America, cousin marriages are illegal under statutes passed in the 19th and 20th centuries [9]. Consanguinity occurs in all countries of the Middle East, however, the prevalence varies significantly, ranging from $10.6 \%$ to $67.7 \%$ [10-18].

In an attempt to investigate the changes in the prevalence of consanguinity over a generation, we conducted this study on a group of university students and educated women attending outpatient clinics in Riyadh and compared the prevalence of consanguinity among the married women in this group, to the prevalence in their parents. 


\section{Methods}

The inclusion of the female subjects for this study was random and voluntary. The purpose of the study was explained, they were invited to enrol and only those who volunteered were included in the study. Each female had to sign a consent form for inclusion. Exclusion criteria included: non-Saudi females and any female suffering from any major sickness. The final study group was 600 healthy Saudi females aged from 16-45 years (26.1 \pm 7.7 years). The study group comprised: (a) 200 students from the Department of Science at the Faculty of Education, Ministry of Education, Al-Malaz, Riyadh, and 221 students from the Department of Arts at King Saud University, Alishia, Riyadh; (b) 179 women (all at least graduates) attending the outpatient clinics at the Security Forces Hospital, Riyadh, for minor illnesses.

Each woman was interviewed in Arabic using a purposedesigned questionnaire that inquired about age, and marital status. If married, the women were asked about consanguinity with their husbands and if the answer was yes, they were asked about the level of consanguinity (i.e. first or second cousins). Furthermore, each woman was asked about the consanguinity of her parents and the degree of consanguinity, if present.

The data was analysed using SPSS version 9. Prevalence rates between groups were compared by chi-square analysis using a $2 \times 2$ contingency table. $P<0.05$ was considered statistically significant.

\section{Results}

The total consanguinity among the parents of the 600 women participants was $29.7 \%$, of whom $23.0 \%$ were first-degree cousins and $6.7 \%$ were second-degree cousins (Table 1). Of the participants' females, 293 were married and the overall prevalence of consanguinity in these females was $37.9 \%$ (Table 1). The prevalence of consanguinity among the married participant women was significantly higher than among the parents of the whole sample $\left(\chi^{2}=5.704, P=0.016\right)$.

Table 1 Prevalence of consanguinity among the participants' parents and among married participants

\begin{tabular}{|c|c|c|c|c|c|c|c|c|}
\hline \multirow[t]{3}{*}{ Group } & \multirow{3}{*}{$\begin{array}{l}\mathrm{N} \quad \mathrm{O} \\
\text { studied }\end{array}$} & \multicolumn{6}{|c|}{ Consanguineous marriage } & \multirow[t]{3}{*}{ F } \\
\hline & & \multicolumn{2}{|c|}{ 1st cousin } & \multicolumn{2}{|c|}{ 2nd cousin } & \multicolumn{2}{|c|}{ Total } & \\
\hline & & No. & $\%$ & No. & $\%$ & No.* & $\%$ & \\
\hline Participants' parents & 600 & 138 & 23.0 & 40 & 6.7 & 178 & 29.7 & 0.024 \\
\hline Participants (married) & 293 & 88 & 30.0 & 23 & 7.8 & 111 & 37.9 & 0.030 \\
\hline
\end{tabular}

$* \chi^{2}=5.704, P=0.016$.

The married females (293) were grouped into six age groups and the prevalence of first- and second-cousin marriages was assessed in each group. Table 2 presents the prevalence of consanguinity in the different age groups. It shows that the prevalence of first cousin marriages was higher in each age group compared to the prevalence of second cousin marriages. Differences were observed in the prevalence of consanguinity in the different age groups; however, the differences were not statistically significant in the different groups.

Table 2 Prevalence of consanguinity in married participants in different age groups

\begin{tabular}{|c|c|c|c|c|c|c|c|c|}
\hline \multirow[t]{3}{*}{ Age (years) } & \multirow[t]{3}{*}{ No. studied } & \multicolumn{2}{|c|}{ Non-consanguineous } & \multicolumn{5}{|c|}{ Consanguineous } \\
\hline & & & & 1 st & & $2 \mathrm{nd}$ & & \\
\hline & & No. & $\%$ & No. & $\%$ & No. & $\%$ & Total \% \\
\hline $16-20$ & 20 & 13 & 65.0 & 6 & 30.0 & 1 & 5.0 & 35 \\
\hline $21-25$ & 75 & 43 & 57.3 & 27 & 36.0 & 5 & 6.7 & 42.7 \\
\hline $26-30$ & 64 & 38 & 59.4 & 21 & 32.8 & 5 & 7.8 & 40.6 \\
\hline $31-35$ & 41 & 31 & 75.6 & 9 & 22.0 & 1 & 2.4 & 24.4 \\
\hline $36-40$ & 54 & 32 & 59.3 & 16 & 29.6 & 6 & 11.1 & 40.7 \\
\hline $41-45$ & 39 & 25 & 64.1 & 9 & 23.1 & 5 & 12.8 & 35.9 \\
\hline Total & 293 & 182 & 62.1 & 88 & 30.0 & 23 & 7.8 & 37.8 \\
\hline
\end{tabular}

Finally, the prevalence of consanguinity in the 293 married females was correlated with the prevalence of consanguinity in their parents and the results are presented in Table 3. Of the 293 married women, $30.0 \%$ were first- and $7.9 \%$ were second-cousin marriages. Among the parents who were non-consanguineous, 
$25.1 \%$ of the daughters were married to first and $4.8 \%$ to second cousins. While in parents who were consanguineous, cousin marriages in their daughters was
$52.3 \%$ (first cousin $38.4 \%$ and second cousin $14.0 \%$ ). This was significantly higher than the prevalence of consanguinity in the daughters of non-consanguineous couples $(P<0.05)$.

Table 3 Correlation between consanguinity in participants' parents and their daughters

\begin{tabular}{|c|c|c|c|c|c|c|c|c|}
\hline \multirow[t]{3}{*}{ Parent's marriage } & \multirow[t]{3}{*}{$\begin{array}{l}\text { Total } \\
\text { No. }\end{array}$} & \multicolumn{2}{|c|}{ Daughter's marriage } & \multicolumn{5}{|c|}{ Consanguineous } \\
\hline & & & & \multicolumn{2}{|c|}{1 st cousin } & \multicolumn{3}{|c|}{ 2nd cousin } \\
\hline & & $\begin{array}{l}\text { No. } \\
142\end{array}$ & $\begin{array}{l}\% \\
68.6\end{array}$ & $\begin{array}{l}\text { No. } \\
55\end{array}$ & $\begin{array}{ll}\% & \\
& 26.6\end{array}$ & No. 10 & $\%$ & 4.8 \\
\hline Consanguineous & 86 & 40 & 46.5 & 33 & 38.4 & 13 & & 15.1 \\
\hline 1 st cousin & 68 & 33 & 48.5 & 29 & 42.6 & 6 & & 8.8 \\
\hline 2 nd cousin & 18 & 7 & 38.9 & 4 & 22.2 & 7 & & 38.9 \\
\hline Total & 293 & 182 & 62.1 & 88 & 30.0 & 23 & & 7.8 \\
\hline
\end{tabular}

\section{Discussion}

The extent of consanguinity in any population is an outcome of the demographic structure of each population, which is dependent on social, traditional and religious factors. Keyfitz and Flieger [19] underlined the importance of social factors and McCullough and O'Rourke [20] explained that differences in the consanguinity levels in different populations may be explained on the basis of these factors. Several studies have shown that consanguinity is responsible for changes in genotype frequencies and results in an increase in the homozygous genotype while decreasing the corresponding heterozygous form [21]. It is considered as an important factor in differentiating populations [22].

This study investigated consanguinity in the parents of 600 women and the prevalence of consanguinity among the 293/600 participant females who were married. The prevalence of consanguinity in the parents was significantly lower compared to the prevalence in the daughters. Comparison of the results of this study with those reported earlier in different provinces of Saudi Arabia, and in other Middle East countries (Table 4), shows several interesting findings.

The total prevalence of first- and second-cousin marriages among our sample of Saudi Arabian women $(37.9 \%)$ is the same, though in the parents the prevalence was lower, than that reported in an earlier study in the total Saudi population [14]. In several studies on Saudi population the consanguinity rates are reported to be above $50 \%$ and the major form is first cousin marriages (Table 4). A few studies have reported second cousin or distant relative marriages, but data on other forms of first cousin marriages, such as first cousin once removed, double first cousin and second cousin once removed is not available. Furthermore, none of the studies have reported data on the prevalence of paternal and or maternal relationship of the cousin marriages. In the present study, first-cousin marriages were more common compared to second-cousin marriages, a trend that is similar to the earlier reports from the Saudi population [14] (Table 4). In the present study, however, the prevalence of second-cousin marriages was much lower than that reported earlier [14] and this may indicate a slight change in the trends of cousin marriages over the past 20-30 years.

Compared with other Middle Eastern countries, which follow the same religion and have similar traditions as Saudi Arabia, the consanguinity rates in our study population are higher than in Bahrain [23], Egypt [24-26] and Lebanon $[27,28]$ but similar to that reported from Oman [29] and Yemen [30] and significantly lower than the rates in Jordan [31-33], Kuwait [34], Iraq [11] and UAE [35]. An interesting finding of our study was that the prevalence of consanguinity in the married women was significantly higher than in their parents. This may be an indication that the prevalence of consanguinity is actually increasing among the Saudi Arabian population. A similar trend was also reported by Al-Ghazzali et al. [35], who showed that in the United Arab Emirates the consanguinity rates in the current generation were higher compared to their parent's generation (50.5\% versus 39.0\%) and by Jurdi and Saxena [30] in Yemen who reported that the prevalence of cousin marriages appeared to have increased over time. However, a study from Norway, on women of Pakistani origin, showed that a decrease in the consanguinity prevalence was the modern trend [36]. 
Table 4 Consanguinity in Saudi Arabian women and their parents: comparison with results from other studies in Saudi Arabia and the Middle East

\begin{tabular}{|c|c|c|c|c|}
\hline \multirow[t]{2}{*}{ Country } & \multicolumn{3}{|c|}{ Consanguineous marriage $(\%)$} & \multirow[b]{2}{*}{ Reference } \\
\hline & $\begin{array}{l}1 \mathrm{~s} \\
\text { cousin }\end{array}$ & 2nd cousin & Total & \\
\hline $\begin{array}{l}\text { Saudi Arabia } \\
\text {--Participants (married) }\end{array}$ & 23.0 & 6.7 & 29.7 & This study \\
\hline -- Participants' parents & 30.0 & 7.8 & 37.9 & \\
\hline Saudi Arabia & 25.8 & $\begin{array}{c}14.8 \\
\text { Distant: } 15.2\end{array}$ & 40.6 & \multirow[t]{6}{*}{14} \\
\hline -Central province & 29.8 & 13.4 & 43.2 & \\
\hline -Northern province & 17.9 & 17.4 & 35.3 & \\
\hline -Northwest province & 27.3 & 20.8 & 48.0 & \\
\hline -Southwest province & 26.0 & 12.4 & 38.4 & \\
\hline - Eastern province & 40.9 & 9.1 & 50.0 & \\
\hline Saudi Arabia (Riyadh) & 42 & Others: 28 & $\begin{array}{c}60.0 \\
\text { Same in parents }\end{array}$ & 55 \\
\hline $\begin{array}{r}\text { Saudi Arabia - Total } \\
\text {-Rural } \\
-\quad \text { Urban }\end{array}$ & 33.6 & 22.4 & $\begin{array}{c}56 \\
59.5 \\
54.7\end{array}$ & 15 \\
\hline Saudi Arabia (Dammam) & 39.3 & 12.7 & 52 & 56 \\
\hline Saudi Arabia (Riyadh) & 31.4 & 22.9 & 54.3 & 57 \\
\hline Bahrain & 21.0 & 7.8 & 28.8 & 23 \\
\hline Egypt & 14.1 & 5.4 & 19.5 & 26 \\
\hline $\begin{array}{ll}\text { Lebanon } & - \text { Muslims } \\
& - \text { Christian }\end{array}$ & $\begin{array}{c}17.3 \\
7.9\end{array}$ & - & $\begin{array}{l}29.6 \\
16.5\end{array}$ & 28 \\
\hline Untied Arab Emirates & $\begin{array}{l}31.5 \\
26.2\end{array}$ & $\begin{array}{c}- \\
24.3\end{array}$ & $\frac{-}{50.5}$ & 35 \\
\hline Iraq & 30.0 & - & 58.0 & 11 \\
\hline Jordan $^{a}$ & 32.0 & 6.8 & 50.0 & 31,32 \\
\hline Kuwait $^{\mathrm{b}}$ & 30.2 & 22.1 & 54.3 & 34 \\
\hline $\mathrm{Oman}^{\mathrm{c}}$ & 24.1 & 11.8 & 35.9 & 29 \\
\hline Yemen & 32.0 & 8.0 & 40.0 & 30 \\
\hline
\end{tabular}

${ }^{a}$ Other distant relation marriages: $10.5 \%$. ${ }^{b}$ Double first cousins: $2.0 \%$.

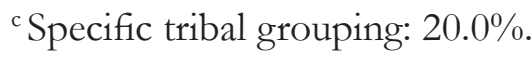

This could be explained on the basis of the significant cultural differences faced by the people who migrate to the developed countries. Many of the younger people who, under the influence of the family agree to arranged marriages, in their country of origin, when they migrate to other countries, the influence of family is lessened and the determination to find a partner of their own choice is elevated, hence the effect on the prevalence of consanguinity. Conversely, immigration could also increase consanguinity prevalence, as people feel more confident and sure with people from their own families.

In this study, our results showed that parents who themselves are consanguineous have a higher prevalence of consanguinity in their daughters, i.e. higher inbreeding rates. Among parents who themselves were married to first cousins, $42.6 \%$ had daughters married to a first cousin and 8.8\% married to a second cousin, while among parents who were themselves married to second cousins, $22.2 \%$ daughters were married to a first cousin while $38.9 \%$ had daughters married to a second cousin. In fact, consanguinity was higher $(61.1 \%)$ in the daughters of parents who were second cousins themselves, compared with $51.5 \%$ in the parents who were themselves first cousins. In this respect, consanguinity was only $30.0 \%$ in the daughters of the parents who were not related. This finding confirms that inbreeding is the preferred option in those couples who are themselves closely related.

Consanguinity has several advantages and several factors 
may operate in the Saudi population to encourage consanguineous marriages. The major factors are the social and economic benefits and the possibility of a more stable marriage among cousins if both members have grown up in a similar environment and therefore adjust more easily after marriage. Anthropologists have long agreed that the major advantage of consanguineous marriages is the inheritance of family structure and property [37-39].

On the other hand, adverse effects of consanguinity in terms of reproductive behaviour, reproductive wastage, higher morbidity and mortality and genetic problems have been described extensively in the literature [10, $17,31,40-50]$. One of the major harmful effects is a higher frequency of rare autosomal recessive disorders in the offspring of consanguineous mating $[17,16]$. In addition, increased rates of morbidity and mortality have been directly related to the degree of inbreeding $[11,48]$. Furthermore, congenital malformations and inborn errors of metabolism have also been shown to occur at a higher rate in the offspring of cousin marriages $[45,47]$.

Studies in the Saudi population have shown that autosomal recessive and other major genetic disorders (58, 61), inflammatory bowel disease (59), familial multiple sclerosis (60), bronchial asthma (62), congenital heart disease $(63,67)$, hearing impairment (64), spina bifida (65), several problems of pregnancy $(57,66)$ and schizophrenia (67), occur at a higher prevalence in consanguineous mating. These finding and others stress the need for decrease in the rate of consanguineous marriages in the Saudi population. In all these studies the rate of consanguineous marriages in the normal controls were above $50 \%$.

Whether religious believes play any role in influencing the prevalence of consanguinity has to be assessed. The Saudi population are all Muslims and marriage regulations permit marriage between first, second cousins and double first cousins. The Holy Quran provides clear guidelines as to who a person can marry and this permits cousin marriages [Chapter 4: verse 23]. A saying of the Prophet Mohammad (Peace be upon him) encourages the people to choose a marriage partner from outside ones family. Prophet Mohammad (Peace be upon him) recommended his followers to marry outside their families and outside their clans. At one occasion, the Prophet (PBUH) told one of his companions to choose a wife from a tribe different to his, and then to choose for his son a wife from a third tribe, and to seek for his other son a girl from yet another tribe.

Several regional differences in the prevalence of consanguinity are prevalent amongst the Saudi [15 ] and since all regions follow the same religion, these differences can only be explained on the basis of differences in education level, financial status, social attitudes and population movement $[15,51,52]$.

One aspect is clear: that it will not be possible to entirely discourage cousin marriages in societies such as that of Saudi Arabia, due to the strong traditions and family values, despite the fact that several genetic diseases are prevalent in this country [53]. However, it is advised that in families with a serious autosomal recessive genetic disorder the practice of consanguinity must be discouraged in an attempt to prevent the birth of an affected child. In this respect, awareness programmes have been implemented in Saudi Arabia to inform people about the frequently encountered genetic problems and their long term consequences. Premarital screening for the frequently encountered genetic disorders has been made obligatory and this is frequently followed by genetic counselling. Result reported after six years of premarital screening in Saudi Arabia has shown marked reduction in the number of at-risk marriages [54], and it has been predicted that this may considerably reduce the genetic disease burden in Saudi Arabia in the next decades.

Conclusion: There is a need for more active awareness programs to inform the general public about the advantages and disadvantages of consanguineous mating, in an attempt to reduce the prevalence of consanguinity in a population where great preference is given to family traditions and values.

\section{Acknowledgement}

This research project was supported by a grant from the research centre of the centre for female scientific and medical colleges in King Saud University

\section{Disclosure of competing interests}

Authors declare that they do not have any competing interests with any group.

\section{Authors' contributions}

ASW designed the experiment, analyzed the data and 
wrote the manuscript. MAJ, SD, AD and MA helped in data analysis, discussion of results and preparation of the manuscript. All authors read and approved the final manuscript.

\section{References}

1. Bittles A. Consanguinity and its relevance to clinical genetics. Clin Genet. 2001;60:89-98.

2. Bittles AH, Mason WM, Greene J, Rao NR. Reproductive behavior and health in consanguineous marriages. Science. 1991;252:789-94.

3. Darwin G. Marriages between first cousins in England and their effects. J.Stat Soc, 1875:38, 153-84.

4. Darwin G. Notes on the marriage of first cousins. J. Stat Soc. 1875;38: 344-8.

5. Bittles AH. Consanguineous marriages, current global incidence and its relevance to demographic research. Research report no. 90-186., 1990. Population Studies Center, Ann Arbor, Michigan.

6. Hamamy H, Bittles AH. Genetic clinics in Arab communities: Meeting individual, family, and community needs. Public Health Genomics, 2009;12:30-40.

7. Bittles AH, Hussain R,. An analysis of consanguineous marriage in the Muslim population of India at regional and state levels. Ann of Hum Biology, 2000;27(2): 163-71.

8. Bittles AH. A community genetics perspective on consanguineous marriage. Com Gen, 2008;11:324-330.

9. Ottenheimer M. Forbidden relatives - the American myth of cousin marriage. University of Illinois Press: Chicago. Illinois. 1996.

10. El-Shafei A, Rao SS, Samdhu AK. Congenital malformation and consanguinity. Australian and New Zealand J Obstetrics Gyncol, 1986;26:168-72.

11. Hamamy HA, Al-Hakkak ZS. Consanguinity and reproductive health in Iraq. Hum Hered, 1989;39:271-5.

12. Chaleby K, Tuma TA. Cousin marriages and schizophrenia in Saudi Arabia. Brit J. of Psychiatry, 1987;150:547-9.

13. Saedi-Wong S, Al-Frayh RA, Wong NYH. Socioeconomic epidemiology of consanguineous mating in the Saudi Arabian population. J Asian African Studies.1989;24:247-51.

14. El-Hazmi MA, al-Swailem AR, Warsy AS, alSwailem AM, Sulaimani R, al-Meshari AA. Consanguinity among the Saudi Arabian population. J Med Genetics.1995;32:623-26.

15. El Mouzan MI, Al Salloum, AA, Al Herbish AS, Qurachi MM, Al Omar AA. Regional variations in the prevalence of consanguinity in Saudi Arabia. Saudi Med J, 2007;28(12):1881-4.

16. El Mouzan MI, Al Salloum, AA, Al Herbish AS,
Qurachi MM, Al Omar AA. Consanguinity and major genetic disorders in Saudi children: a community-based cross-sectional study. Ann Saudi Med, 2008;28(3):16973.

17. Ozand PI, Rashed MS. Inborn errors of metabolism in the Middle East. Symposium on Epidemiologic Transition/Transaction and Health in Developing Countries, College of Medicine, King Saud University, 1994:27-29 November. Riyadh

18. Hassnan ZN, Sakati N, Genetic Disorders in Saudi Arabia. In Teebi, A.S. ed. Genetic Disorders Among Arab Populations ( $2^{\text {nd }}$ ed), Springer-Verlag Berlin Heidelberg, 2010; 531.

19. Keyfitz N, Flieger W. Demografia: metodos estadtsticos. Ediciones Marymar: Buenos Aires, Argentina. 1975.

20. McCullough JM, O'Rourke DH. Geographic distribution of consanguinity in Europe. Ann Hum Biol, 1986;13(4):359-67.

21. Thompson MW, McInnes RR, Willard HF. Genetics in Medicine, 5th ed. Saunders: London. 1991.

22. Roberts DF, Genetic studies of isolates. In: Emery $\mathrm{AEH}$, ed. Modern trends in human genetics. Butterworths: London. 1975;221-69.

23. Al-Arrayed S. Consanguinity in the State of Bahrain. In: El-Hazmi MAF, ed. Proceedings of the symposium on medical genetics in the setting of Middle Eastern populations. King Abdul Aziz Centre for Science and Technology Press: Riyadh. 1995.

24. Hussein FH. Endogamy in Egyptian Nubia. J Biosoc Sci, 1971;3:351-7.

25. Badr FM. Genetic studies of Egyptian Nubian populations. I. Frequency of types of consanguineous marriages. Hum Heredity, 1972;22:387-98.

26. Hafez M, El-Tahan H, Awadalla M, El-Khayat H, Abdel-Gafar A, Ghoneim M. Consanguineous matings in the Egyptian population. J Med Genet, 1983;20: $58-60$.

27. Loiselet J, Karayacougoblou J, Boustany N, Khouri R. Blood lipids in a group of young Lebanese. II. J Med Liban. 1971;24(6):541-70.

28. Khlat M. Consanguineous marriage and reproduction in Beirut, Lebanon. Amer J Hum Genet, 1988;43:188-96.

29. Rajab A, Patton MA. A study of consanguinity in the Sultanate of Oman. Ann Human Biol, 2000;27:321-6. 30. Jurdi R, Saxena, PC. The prevalence and correlates of consanguineous marriages in Yemen. Similarities and contrasts with other Arab countries. J Biosoc Sci, 2003;35:1-13.

31. Cook R, Hanslip A. Mortality among offspring of 
consanguineous marriage in a rural area of East Jordan. J Trop Pediatrics, 1966;11:95-9.

32. Khoury SA, Massad D. Consanguineous marriage in Jordan. Amer J Med Genet, 1992;43:769-75.

33. Al-Salem M, Rawashdeh $\mathrm{N}$. Consanguinity in north Jordan: prevalence and pattern. J Biosoc Sci, 1993;25:553-6.

34. Al-Awadi SA, Moussa MA, Naguib KK, Farag TI, Teebi AS, el-Khalifa M, el-Dossary L. Consanguinity among the Kuwaiti population. Clin Genet, 1985;27: 483-6.

35. Al-Gazali LI, Bener A, Abdulrazzaq YM, Micallef R, al-Khayat AI, Gaber T. Consanguineous marriages in the United Arab Emirates. J Biosoc Sci, 1997;29: 491-7.

36. Grjibovski AM, Magnus P, Stoltenberg C. Decrease in consanguinity among parents of children born in Norway to women of Pakistani origin: A registry-based study. Scand J Pub Health, 2009;37:232-238.

37. Granguist H. Marriage conditions in a Palestinian village. Parts I and III. Soderstrom: Helsinki. 1931.

38. Riesenfeld A. An analysis of marriage and marriage statistics for a Muslim and Christian Arab village. Int Arch Ethnogr, 1957;68:32.

39. Schull WJ, Neel JV. The effects of parental consanguinity and inbreeding in Hirado, Japan. V. Summary and interpretation. Amer J Med Genet, 1972;24:42553.

40. Al-Awadi SA, Naguib KK, Moussa MA, Farag TI, Teebi AS, el-Khalifa MY. The effect of consanguineous marriages on reproductive wastage. Clin.Genet, 1986;29:384-8.

41. Zakzouk S., El-Sayed Y, Bafaqeeh SA. Consanguinity and hereditary hearing impairment among Saudi population. Ann Saudi Med, 1993;13:447-50.

42. Shami SA, Schmitt LH, Bittles, AH, Consanguinity, spousal age at marriage and fertility in seven Pakistani Punjab cities. Annals of Human Biology, 1990.17, 97-105.

43. Sakati N, Congenital malformation as a health problem model in developing countries. Symposium on Epidemiologic Transition/Transaction and Health in Developing Countries, College of Medicine, King Saud University. 27-29 November. Riyadh. 1994.

44. Khoury SA, Mossad DF. Consanguinity fertility, reproductive wastage, infant mortality and congenital malformation in Jordan. Saudi Med J, 2000; 21:150-4. 45. Stoltenberg C, Magnus P, Skrondal A, Lie RT. Consanguinity and recurrence risk of stillbirth and infant death. Amer J Pub Health, 1999;89:517-23.

46. Zlotogora J. What is the birth defect risk associated with consanguineous marriage? Amer J Med Genet, 2002;109:70-71.

47. Bromiker R, Glam-Baruch M, Gofin R, Hammerman C, Amitai Y. Association of parental consanguinity with congenital malformations among Arab newborns in Jerusalem. Clin Genet, 2004;66:63-66.

48. Bittles AH, Grant JC, Sullivan SG, Hussain R. Does inbreeding lead to increased human fertility? Ann Human Biol, 2002;29:111-131.

49. Bittles AH. Consanguinity, genetic drift, and genetic diseases in populations with reduced numbers of founders. In Human Genetics: Principles and Approaches, eds Vogel F, Motulsky AG, Antonarakis SE, Speicher M, 4th Ed. Springer: Heidelberg. 2009.

50. Bittles AH, Black ML. Consanguinity, human evolution, and complex diseases PNAS, 2010;107:1779_ 1786

51. Bittles AH. The bases of Western attitudes to consanguineous marriage. Dev Med Child Neurol, 2003;.45:135-138.

52. Paul DB, Spencer HG. "It's OK, we're not cousin by blood": The cousin marriage controversy in historical perspective. PLoS Biol. 2008;6:e320.

53. El-Hazmi MAF, Warsy AS. Genetic disorders among Arab populations. Saudi Med J. 1996;17:108-123.

54. Memish ZA, Saeedi MY. Six-year outcome of the national premarital screening and genetic counseling program for sickle cell disease and $\beta$-thalassemia in Saudi Arabia. Ann Saudi Med. 2011;31(3):229-35

55. El Mouzan M, Al-Mofarreh M, Assiri A, Hamid Y, Saeed A. Consanguinity and inflammatory bowel diseases: is there a relation? J Pediatr Gastroenterol Nutr. 2013;56(2):182-5..

56. al-Abdulkareem AA, Ballal SG. Consanguineous marriage in an urban area of Saudi Arabia: rates and adverse health effects on the offspring. J Community Health. 1998;23(1):75-83.

57. Wong SS, Anokute CC. The effect of consanguinity on pregnancy outcome in Saudi Arabia. J R Soc Health. 1990;110(4):146-7.

58. Al-Owain M, Al-Zaidan H, Al-Hassnan Z. Map of autosomal recessive genetic disorders in Saudi Arabia: concepts and future directions. Am J Med Genet A. 2012;158A(10):2629-40.

59. El Mouzan M, Al-Mofarreh M, Assiri A, Hamid Y, Saeed A. Consanguinity and inflammatory bowel diseases: is there a relation? J Pediatr Gastroenterol Nutr. 2013;56(2):182-5..

60. Al Jumah M, Kojan S, Al Khathaami A, Al Abdulkaream I, Al Blawi M, Jawhary A. Familial multiple sclerosis: does consanguinity have a role? Mult Scler. 
2011;17(4):487-9.

61. El Mouzan MI, Al Salloum AA, Al Herbish AS, Qurachi MM, Al Omar AA. Consanguinity and major genetic disorders in Saudi children: a community-based cross-sectional study. Ann Saudi Med. 2008;28(3):16973.

62. El Mouzan MI, Al Salloum AA, Al Herbish AS, Al Omar AA, Qurachi MM. Does consanguinity increase the risk of bronchial asthma in children? Ann Thorac Med. 2008;3(2):41-3.

63. Becker S, Al Halees Z. First-cousin matings and congenital heart disease in Saudi Arabia. Community Genet. 1999;2(2-3):69-73.

64. Zakzouk S. Consanguinity and hearing impairment in developing countries: a custom to be discouraged. J Laryngol Otol. 2002;116(10):811-6.

65. Murshid WR. Spina bifida in Saudi Arabia: is consanguinity among the parents a risk factor? Pediatr Neurosurg. 2000;32(1):10-2.

66. al-Eissa YA, Ba'Aqeel HS. Risk factors for spontaneous preterm birth in a Saudi population. Eur J Obstet Gynecol Reprod Biol. 1994;57(1):19-24.

67. Becker SM, Al Halees Z, Molina C, Paterson RM. Consanguinity and congenital heart disease in Saudi Arabia. Am J Med Genet. 2001 15;99(1):8-13.

68. Chaleby K, Tuma TA. Cousin marriages and schizophrenia in Saudi Arabia. Br J Psychiatry. 1987;150:547-9. 